\title{
Using Scientific Identification Theory for Operational Research in Education for analyzing Teachers' Performance
}

\author{
Darmawi*, Soewarto Hardhienata, Rita Retnowati \\ Postgraduate Program, Pakuan University Bogor, Indonesia
}

*Corresponding Author: Darmawi, Postgraduate Program, Pakuan University Bogor, Indonesia

\begin{abstract}
The purpose of this study is to find out endeavors to improve teacher performance through organizational culture, academic supervision, and emotional intelligence by referring to Scientific Identification Theory for Operational Research in Education. Organizational culture, academic supervision, and emotional intelligence variables serve as independent variables, and teacher performance is the dependent variable. The number of research samples of 138 teachers was taken with proportional random sampling, and hypothesis testing was followed with qualitative analysis through Focus Group Discussion.

The results of this study concluded that there is a positive relationship reinforced by qualitative research for variables a) organizational culture with teacher performance with a correlation coefficient $=0.494$ and the coefficient of determination $=0.244, b$ ) academic supervision with teacher performance with a correlation coefficient $=0.327$ and the coefficient of determination $=0.107, c)$ emotional intelligence with teacher performance with correlation coefficient $=0.221$ and coefficient of determination $=0.049$, and $d$ ) organizational culture, academic supervision and emotional intelligence together with teacher performance with a coefficient correlation $=0.591$, and the coefficient of determination $=0.350$. The implication with Scientific Identification Theory for Operational Research in Education is discussed further.
\end{abstract}

Keywords: Organizational Culture, Academic Supervision, Emotional Intelligence, Teacher Performance

\section{INTRODUCTION}

The success of the implementation of education is strongly associated with the success of increasing the competence and professionalism of educators and education personnel (Hamid et al., 2012). This implies that the role of the teacher is placed in a strategic position in providing knowledge services to students as subjects and objects in learning. However, how good the curriculum and complete facilities are, but if not supported by teacher performance, the learning process does not work optimally (Ayeni, 2012). Therefore, to achieve a quality education process by the expectations of the government and society, there are several aspects of education that can support the achievement of educational goals, among others, teacher performance and educational supervision.

Supervision is based on objective data and facts. The success of academic supervision is also supported by corporate relations, namely relationships that are built intently and warmly by humanity by upholding the dignity and dignity of the teacher. The warm and familiar atmosphere of academic supervision makes teachers feel comfortable so that supervisors can help develop togetherness in improving teacher skills (Sudarwan, 2010).

Academic supervision means fostering teachers in enhancing the quality of the learning process in order to improve the quality of student learning outcomes. Aspects that are fostered are related to the learning process where the teacher's focus is to be professional in teaching (Hoy \& Miksel, 2008). The role of professional teachers is essential to realize the national education goals, namely to educate the life of the nation and develop humanity as a whole, according to the Law of the Republic of Indonesia Number 20 of 2003 concerning the National Education System. In carrying out duties, a teacher must have the knowledge and skills by the development of science and technology so that they can carry out their performance well (Hanif \& Prawironegoro, 2009).

Organizational culture is also called the work climate that describes the atmosphere and working relationships between fellow teachers, between teachers and the head of the madrasa, between 
teachers and other education personnel and between services in their environment as a manifestation of a conducive work environment (Rajiani, 2010). This atmosphere is very much needed by teachers and principals to carry out their work more effectively.

The role of EQ (Emotional Quotient) in a person is all the ability to understand one's feelings, to empathize with other people's feelings and to regulate emotions, which together in achieving goals (Malik \& Tariq, 2016). If the madrasah supervisor does not have emotional intelligence, then in carrying out his duties he will always be angry with teachers who do not fit.

Emotional intelligence has been received and acknowledged its usefulness. This is evident that a professional madrassa supervisor who is technically superior and has a high emotional intelligence are the ones who are able to resolve the conflict, see the gaps that need to be bridged or filled, see hidden connections that promise opportunities, interact, considerably to produce more valuable, better prepared, more agile, and faster than others (Puspitasari, 2016). Emotional intelligence is critical for madrasah supervisors to have as supervisors for madrasas must be able to motivate to create something that can build madrasas to be better.

The performance of individual teachers in an institution will significantly influence the institution's progress and withdrawal (Lunenburg and Ornstien 2000). Likewise, the quality of education is inseparable from the role of individual teacher performance in improving education quality. High and low teacher productivity in carrying out their duties is determined by the high and low performance of teachers in the madrasa.

This teacher's performance has to do with academic supervision carried out by the madrasa supervisor. Supervision, especially in the field of academics that are less professional will lead to poor teacher performance (Balkar, 2015). There is a strong tendency that to improve service quality in the professional qualifications of teachers who need to be nurtured and reorganized is their ability so that in turn it can be used to direct the teacher program to become a professional figure in education. This is inseparable from the help and guidance of the supervisor. In carrying out its duties, a supervisor is obliged to help the teacher provide support that can carry out the task both as an educator and teacher. As professional teachers, they must have particular expertise and can master the intricacies of education and teaching with various sciences that need to be nurtured and developed through a certain period of education (Rohiat, 2008). The level of success of teacher performance achieved can be known through academic supervision activities.

The performance of these teachers also has to do with organizational culture. The relationship between organizational culture and teacher performance is very close. Undisciplined organizational culture will lead to lack of discipline in the performance of teachers in all things, both in planning learning programs, implementing learning and evaluation of learning (Usman, 2000).

Emotional intelligence is crucial for teachers in carrying out their duties. The emotional intelligence of a teacher plays an essential role in improving performance in teaching and interacting with all components of the school, especially students (Wahyuddin, 2016). The ability of emotional intelligence will have an impact on the success of the teacher in managing interactions between teachers and students, between students and other students so that a teacher can maintain and control class order, manage learning activities so that active learning occurs.

Therefore this study aims to determine the effect of improving teacher performance through organizational culture, academic supervision, and emotional intelligence.

\section{RESEARCH METHODOLOGY}

This study applies a Sequential Explanatory Design Mixed Method where quantitative studies are examined to examine the relationship between variables tested in the study using three independent variables through data obtained from questionnaires (Cresswell, 2010). The research variables consisted of three independent variables namely organizational culture $\left(\mathrm{X}_{1}\right)$, academic supervision $\left(\mathrm{X}_{2}\right)$ and emotional intelligence $\left(\mathrm{X}_{3}\right)$ with the dependent variable namely teacher performance $(\mathrm{Y})$.

The population of this study was all private Madrasah Tsanawiyah (MT) teachers in Merangin district in Jambi Province consisting of 25 private MTs and 210 teachers. The sample in this study was taken using techniques of Proportional Random Sampling. This is done because the population has 
members/elements that are not homogeneous. Determination of the sample size in this study using the Taro Yamane formula obtaining the sample size of 138 respondents. The collected data is made a description statistic which is then carried out by testing hypotheses through test requirements analysis, namely by way of normality test using the Liliefors formula, variance homogeneity test using the Bartlett test, and simple and multiple correlation tests ( Sugiyono, 2013).

\section{Results}

The results of the calculation of the estimated normality test for Teacher Performance variable (Y) on the Organizational Culture variable (X1) obtained the value of 0.0618 which is smaller than the critical value at the level significance of 0.05 , thus it can be concluded that the estimation of Teacher Performance (Y) on Organizational Culture variables comes from populations that are normally distributed. Similarly, the same result is also found for estimated normality test for variable Teacher Performance $(\mathrm{Y})$ for Academic Supervision $(\mathrm{X} 2)$ produces $=0.0548$, and the normality test of variable Teacher Performance $(\mathrm{Y})$ on Organizational Culture $(\mathrm{X} 3)=0.0621$ which are smaller than the critical values. Further, the results of the homogeneity test calculation of teacher performance on the Organizational Culture variable (X1) obtained a value of $\chi 2$ count of 24.806 while $\chi 2$ tables at the significance level $\alpha=0.05$ were 49.802 . Thus it can be concluded that the data group teacher performance on organizational culture variables comes from a homogeneous population. Similarly, the calculation of the homogeneity test of the Teacher Performance variable (Y) on the Academic Supervision variable (X2) produces a value of 29.927, while the table at $\alpha=0.05$ is 33. 924. Because the value is $<\chi 2$ tables, it can be concluded that the data group of teacher performance on the Academic Supervision variable comes from a homogeneous population. Also, the calculation of the homogeneity test of the Teacher Performance variable (Y) on the emotional intelligence variable (X3) indicates the value of $45.439<\chi 2$ tables, $(55.758)$ it can be concluded that the data group teacher performance on the variable emotional intelligence comes from a homogeneous population.

Based on the results of hypothesis testing shows that there is a functional relationship between organizational culture and teacher performance with regression equation $\mathrm{Y}=65.85+0.39 \mathrm{X} 1$ and the value of Fcount $=43.863>$ Ftable $(\alpha=0.05)=3.91$ shows that the significance of regression between organizational culture variables and teacher performance is very significant. In the regression equation model $\mathrm{Y}=65.85+0.39 \mathrm{X} 1$, the constant of 65.85 states that if there is no increase in value from the Organizational Culture variable, the value of teacher performance is 65.85 , while the regression coefficient of 0.39 states that each addition of one score then the performance teacher's will give a score increase of 0.39 . The value of the correlation coefficient obtained is 0.494 indicating that each increase in the score of the Organizational Culture can improve Teacher Performance. The coefficient of determination between Organizational Culture and Teacher Performance is Ry $1^{2}=0.2440$. This means $24.40 \%$ of teacher performance is the result of the workings of Organizational Culture, while $75.60 \%$ is contributed by other variables that have a relationship with improving Teacher Performance. The findings obtained in this study indicate that Organizational Culture is a set of underlying assumptions and values that are understood and implemented together prove effective and valuable to be taught to new members to perceive thinking and feeling related to solving organizational problems.

Based on the results of previous studies, it has been proven that Organizational Culture has a relationship with teacher performance. Based on the analysis of the results of qualitative research through observation, interviews, FGDs and documentation studies, it was shown that Organizational Culture in the teacher population of the private madrasah in Merangin Jambi district had the same tendency as the Organizational Culture obtained quantitatively. The development of diversity in the madrasa requires good organizational thinking and culture so that the teacher's performance is excellent. The results of quantitative research reinforced by qualitative research that organizational culture contributes $24.4 \%$ to teacher performance. Thus madrasas that have an excellent organizational culture is expected to have high-performing teachers.

Based on the results of hypothesis testing shows that there is a functional relationship between Academic Supervision and teacher performance with the regression equation $\mathrm{Y}=47.93+0.52 \mathrm{X}_{2}$ and the calculated $F$ value $=16.313>F_{\text {table }}(\alpha=0.05)=3.91$ shows that regression significance between the Academic Supervision variables and teacher performance is very significant. 
In the regression equation model $\mathrm{Y}=47.93+0.52 \mathrm{X}_{2}$, a constant of 47.93 states that if there is no increase in the value of the Academic Supervision variable then the value of teacher performance is 47.93, while the regression coefficient of 0.52 states that each addition of one score then the teacher's performance will give a score increase of 0.52 .

The correlation coefficient obtained is 0.327 indicating that any increase in Academic Supervision scores can improve Teacher Performance. The value of the coefficient of determination between Academic Supervision and Teacher Performance is $\mathrm{R}_{\mathrm{y} 2}{ }^{2}=0.1069$. This means $10.69 \%$ Teacher Performance is the result of the work of Academic Supervision, while $89.31 \%$ is contributed by other variables that have a relationship with improving Teacher Performance. The findings obtained in this study indicate that Academic Supervision is a service to assist teachers in the form of guidance in improving learning according to the desire to meet needs and even exceed teacher expectations.

Based on the analysis of qualitative research results through observation, interviews, FGDs and studies documentation showed that Academic Supervision in the teacher population of the Merangin Jambi Private Islamic School Madrasah has the same tendency with Academic Supervision obtained quantitatively. The development of diversity in the madrasa requires high academic thinking and supervision so that the teacher's performance is excellent. Based on the results of research quantitative reinforced by qualitative research that Academic Supervision contributes $10.7 \%$ to teacher performance. Thus madrasas that have high academic supervision of teachers are expected to have high-performing teachers as well.

Based on the hypothesis testing results show that there is a functional relationship between Emotional Intelligence with teacher performance regression equation $\mathrm{Y}=58.35+0,43 \mathrm{X}_{3}$ and $\mathrm{F}$ count $=7.01>\mathrm{F}_{\text {table }}$ $(\alpha=0.05)=3.91$, shows that the regression significance between the variables of Emotional Intelligence and teacher performance is very significant.

In the regression equation model $\mathrm{Y}=58.35+0.43 \mathrm{X}_{3}$, the constant of 58.35 states that if there is no increase in value from the variable Emotional Intelligence, the value of teacher performance is 58.35, while the regression coefficient of 0.43 states that each addition of one score then the teacher's performance will give a score increase of 0.43 .

The correlation coefficient obtained is 0.221 indicating that every increase in the score of Emotional Intelligence can improve Teacher Performance. The coefficient of determination between Emotional Intelligence and Teacher Performance is $\mathrm{R}_{\mathrm{y} 3}{ }^{2}=0.0488$. This means $4.88 \%$ Teacher Performance is the result of the work of Emotional Intelligence, while $95.12 \%$ is contributed by other variables that have a relationship with improving Teacher Performance. The findings obtained in this study indicate that Emotional Intelligence is a characteristic of a person in managing feelings to balance feelings, thoughts, and actions that function as a controlling rope so that it is expressed appropriately and effectively that allows people to work together with others smoothly towards a common goal.

Based on the results of previous studies, it has been proven that Emotional Intelligence has a positive direct effect on teacher performance, (Malik \& Tariq, 2016). The results of his research show that there is a significant relationship between emotional intelligence variables and teacher performance. The higher the emotional intelligence that is owned, the higher the performance. The better a person's ability to remain able to think realistically, logically, and not prioritize excessive emotional reactions when facing difficulty, the higher the awareness of the tasks and responsibilities that must be resolved by the individual.

Based on the analysis of qualitative research results through observation, interviews, FGDs and studies documentation showed that Emotional Intelligence in the teacher population of the Merangin Jambi Private Madrasah Tsunami has the same tendency with Emotional Intelligence obtained quantitatively. The development of diversity in the madrasa requires and thinking emotional intelligence high so that the teacher's performance is excellent.

Based on the results of research quantitative reinforced by qualitative research that Emotional Intelligence has contributed $4.88 \%$ to teacher performance. Thus madrasas that have high emotional intelligence teachers are expected to have high-performing teachers as well.

Based on the results of hypothesis testing shows that there is a functional relationship between Organizational Culture, Academic Supervision, and Emotional Intelligence together with Teacher 
Performance with the regression equation $\hat{\mathrm{Y}}=14.07+0.37 \mathrm{X}_{1}+0.48 \mathrm{X}_{2}+0.19 \mathrm{X}_{3}$ and the value $\mathrm{F}$ count $=24.00>\mathrm{F}$ table $(\alpha=0.05)=6.82, \mathrm{~F}$ table $(\alpha=0.01)=3.91$, indicating that the significance of regression between variables Organizational Culture and Academic Supervision together with Teacher Performance is very significant.

In the regression equation model $\hat{\mathrm{Y}}=14.07+0.37 \mathrm{X}_{1}+0.48 \mathrm{X}_{2}+0.19 \mathrm{X}_{3}$, a constant of 24.00 states that if there is no increase in the value of the variable Organizational Culture, Academic Supervision, and Emotional Intelligence together -Same then the value of teacher performance is 24.00, while the regression coefficient of $0.37,0.48$ and 0.19 states that each additional one scores, the performance of the teacher will give rise to a score of $0.37,0.48$ and 0,19 .

The value of the correlation coefficient obtained is 0.591 indicating that each increase in the score of Organizational Culture, Academic Supervision and Emotional Intelligence together increases Teacher Performance. The coefficient of determination between Organizational Culture and Emotional Intelligence together with Teacher Performance is $\mathrm{R}_{\mathrm{y} 1232}=0.3493$. This means $34.93 \%$ Teacher Performance is the result of the work of Organizational Culture, Academic Supervision and Emotional Intelligence together, while the remaining $65.07 \%$ is contributed by other variables that have a relationship with improving Teacher Performance.

Based on the analysis of qualitative research results through observation, interviews, FGDs and documentation studies showed that Organizational Culture, Academic Supervision and Emotional Intelligence in the teacher population of the Merangin Jambi Private Madrasah Tsunami have the same tendency as the Organizational Culture, Academic Supervision and Emotional Intelligence obtained quantitatively. The development of diversity in madrasas requires thinking and organizational culture, high academic supervision and emotional intelligence, so that teacher performance is excellent. Based on the results of research quantitative reinforced by qualitative research that Organizational Culture, Academic Supervision, and Emotional Intelligence together have contributed $34.93 \%$ to teacher performance. Thus madrasas that have good Organizational Culture, Academic Supervision, and Emotional Intelligence, it is hoped that there will be highperforming teachers as well.

\section{DISCUSSION}

Discussion of the results of this study is presented about the results of regression analysis and correlations between variables Organizational Culture $\left(\mathrm{X}_{1}\right)$, Academic Supervision $\left(\mathrm{X}_{2}\right)$, and Emotional Intelligence $\left(\mathrm{X}_{3}\right)$ both individually and jointly with Performance variables Teacher $(\mathrm{Y})$ at the Tsunami Islamic School in Merangin Jambi. Analysis Results of Scientific Identification For Operation Theory Research In Education Management (SITOREM) as proposed by Hardhienata (2017) is shown below:

Based on the picture above it can be said that there is a direct relationship of organizational culture, academic supervision, and intelligence emotional with teacher performance, with correlation coefficient ry $1,=0.494$, ry $2=0.327$ and ry $3=0.221$ this means that with increasing organizational culture, it can improve teacher performance, academic supervision and good emotional intelligence can improve teacher performance.

Further optimization analysis reveals that indicators of organizational culture, namely the pattern of basic assumptions have an significance of 50\% with an empirical finding of an average of 3.57, the value of the pattern of values has an essential meaning of $30 \%$ with an empirical finding of an average of 4.02 , and a pattern of behavior and results of work means $20 \%$ with an average empirical finding of 4, 05. All of these indicators affect teacher performance, meaning that the better the organizational culture, the higher the teacher's performance. This reinforces the results of quantitative research that significantly proves the first hypothesis of this study that there is a positive relationship between organizational culture and teacher performance with a regression equation that is very significant and shows that an increase in the score of organizational culture will increase teacher performance.

To sum up , the indicators of Academic Supervision, namely fostering teachers in choosing and using strategies / methods / learning techniques have an important meaning of $40 \%$ with empirical findings averaging 2.77 , the value of guiding teachers in preparing learning implementation plans (RPP) significance of $20 \%$ with an average empirical findings 4.22, Monitor the value of teachers in 
implementing the learning activity has a meaning $15 \%$ with an average empirical findings 4.47 , value Guide teachers in preparing the syllabus means $5 \%$ by empirical findings on average 4.69 , Guiding value in carrying out research means $5 \%$ with empirical findings averaging 4.83 , the value of Train teachers in utilizing information technology in learning means 5\% with empirical findings on average 4.90, value Guiding teachers in managing, caring for, developing and using educational media and learning facilities means $5 \%$ with average empirical findings of 4, 93, and grades Guiding teachers in assessing process and learning outcomes means $5 \%$ with empirical findings averaging 4.93. All of these indicators affect teacher performance, meaning that the better the academic supervision of the organization, the higher the teacher's performance. This reinforces the results of quantitative research that proves significantly the second hypothesis of this study that there is a positive relationship between academic supervision and teacher performance with a regression equation that is very significant and shows that any increase in academic supervision scores will increase teacher performance.

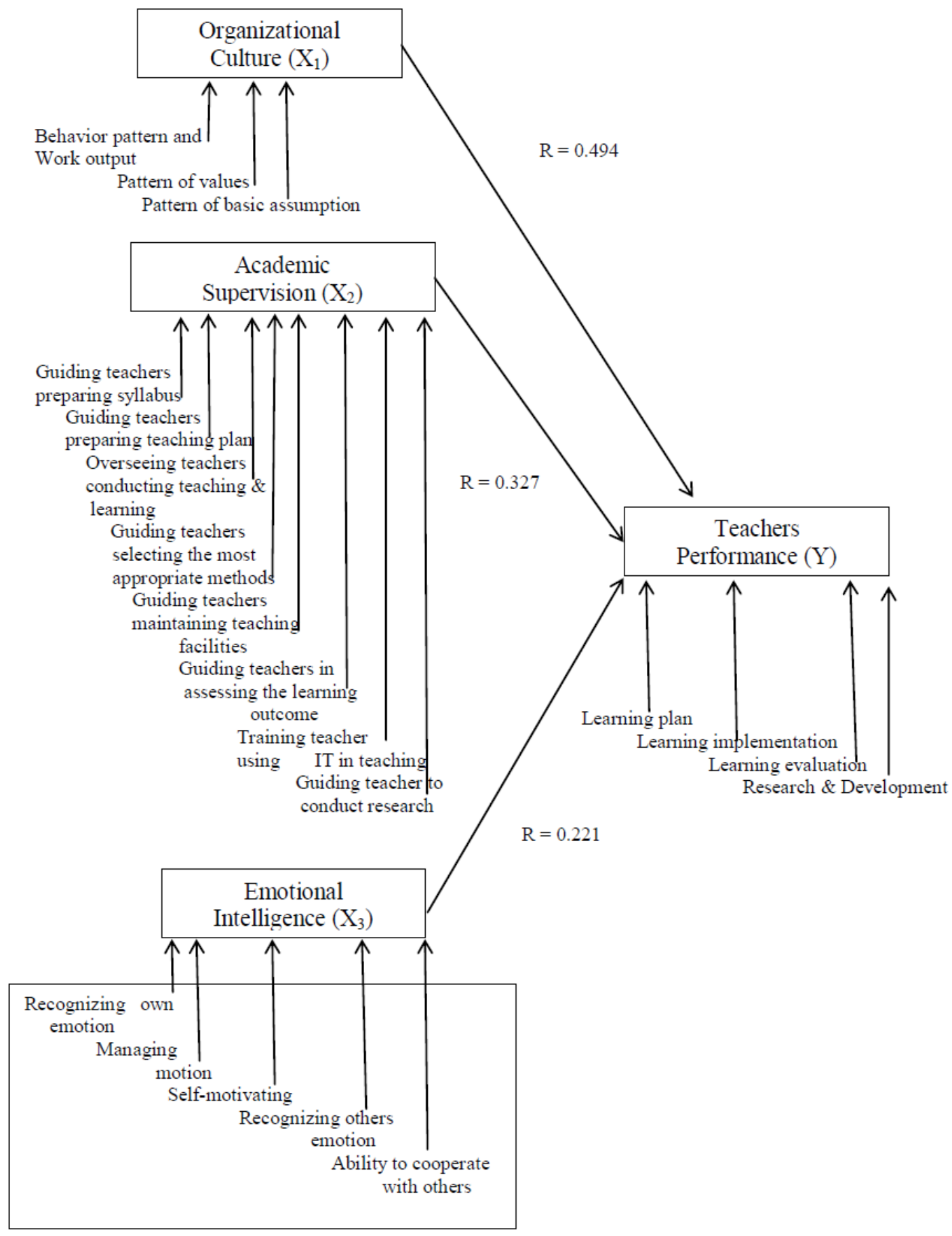

Figure1. Analysis of Scientific Identification of Theory for Operational Research in Education 
Based on the picture above that the indicators of emotional intelligence, namely Managing Emotions have an important meaning of $40 \%$ with an empirical finding of an average of 3.26 , the value of recognizing self-emotion has an important meaning of $30 \%$ with an empirical finding of an average of 4.54, the value Self-motivating means $15 \%$ with empirical findings averaging 4.66, the value of recognizing other people's emotions (empathy) means $10 \%$ with empirical findings averaging 4.38 , and the value of the ability to foster cooperative relationships with others has a meaning of $5 \%$ with an average empirical finding of 4.83. All of these indicators affect teacher performance, meaning that the better emotional intelligence, the higher the teacher's performance. This reinforces the results of quantitative research that proves significantly the third hypothesis of this study that there is a positive relationship between emotional intelligence and teacher performance with a regression equation that is very significant and shows that every increase in emotional intelligence scores, it will increase teacher performance.

The positive relationship between independent variables and dependent variables when viewed from regression analysis, the relationship is a functional relationship where Teacher Performance is formed as a result of the workings of the functions of Organizational Culture, Academic Supervision, and Emotional Intelligence.

In a study that has been conducted in private MTs Merangin Jambi district, has been testing the hypothesis as a whole against the seven hypothesis testing using Pearson Product Moment Correlation and through the application of SPSS, showed that there is a positive relationship between the culture of the organization with the performance of teachers; there is a positive relationship between academic supervision and teacher performance; there is a positive relationship between emotional intelligence and teacher performance; there is a positive relationship between organizational culture and supervision academic with teacher performance; there is a positive relationship between organizational culture and emotional intelligence with teacher performance; there is a positive relationship between supervision academic and intelligence with teacher performance; and there is a positive relationship between organizational culture, academic supervision and intelligence together with teacher performance.

\section{CONCLUSION}

From the discussion of research on the relationship between the variables of Organizational Culture $\left(\mathrm{X}_{1)}\right.$, Supervision of Academic $\left(\mathrm{X}_{2)}\right.$, Emotional Intelligence $\left(\mathrm{X}_{3}\right.$ jointly to the Teacher Performance $(\mathrm{Y})$ gives the following conclusion:

- There is a positive relationship and very significant between Organizational Culture (X1) and teacher performance (Y), meaning that the stronger the Organizational Culture, the stronger the teacher's performance will be. With the ry1 correlation coefficient of 0.494 and the coefficient of determination, $\mathrm{r} 2 \mathrm{y} 1$ is 0.2440 . The contribution of Organizational Culture to teacher performance is $24.40 \%$. The functional relationship between Organizational Culture and teacher performance is shown in the regression equation $\hat{Y}=65.85+0.39 \mathrm{X} 1$.

- There is a positive and significant relationship between Academic Supervision $\left(\mathrm{X}_{2}\right)$ and teacher performance (Y), meaning that the stronger Academic Supervision is, the stronger the teacher's performance, with the ry 2 correlation coefficient of 0.327 and the coefficient correlation $\mathrm{r} 2 \mathrm{y} 2$ of 0.107 . Academic Supervision's contribution to teacher performance is $10.69 \%$. The functional relationship between Academic Supervision and teacher performance is shown by the regression equation $\hat{Y}=47.93+0.52 X_{2}$.

- There is a positive and significant relationship between emotional intelligence $\left(\mathrm{X}_{3}\right)$ and teacher performance $(\mathrm{Y})$, meaning that the stronger emotional intelligence, the stronger the performance teacher, with a ry 3 correlation coefficient of 0.221 and a coefficient correlation r2y3of 0.0488 . The contribution of emotional intelligence to teacher performance is $4.88 \%$. Functional relationship between innovativeness and teacher performance is shown in the regression equation $\hat{\mathrm{Y}}=58.35+0.43 \mathrm{X}_{3}$

- There is a significant positive relationship between Organizational Culture $\left(\mathrm{X}_{1}\right)$, Academic Supervision $\left(\mathrm{X}_{2}\right)$ and Emotional Intelligence $\left(\mathrm{X}_{3}\right)$ together -as the teacher's performance $(\mathrm{Y})$, meaning that the stronger the Organizational Culture, Academic Supervision and emotional 
intelligence, the stronger the teacher's performance, with the ry123 correlation coefficient of 0.591 , the coefficient correlation r2y123 of 0.3493. The contribution of Organizational Culture, Academic Supervision, and emotional intelligence to teacher performance is $34.93 \%$.

\section{REFERENCES}

[1] Ayeni, AJ, (2012). Assessment of Principals' Supervisory Roles for Quality Assurance In Secondary Schools in Ondo State, Nigeria, World Journal of Education. (2).1.

[2] Balkar, B. (2015). The Relationships between Organizational Climate, Innovative Behavior and Job Performance of Teachers. International Online Journal of Educational Sciences, 7 (2), 81-92.

[3] Cresswell, JW Research Design: Pendekatan Kualitatif, Kuantitatif Dan Mixed, Edisi Ketiga, .Yogyakarta: Pustaka Pelajar, 2010.

[4] Hamid, ASR, Syed Hassan, SS, \& Ismail, NH (2012). Teaching Quality and Performance Among Experienced Teachers in Malaysia. Australian Journal of Teacher Education, 37(11).

[5] Hanif, I \& Prawironegoro, D.( 2009.) Sistem Pengendalian Manajemen Konsep dan Aplikasi (Jakarta. Mitra Wacana Media.

[6] Hardhienata, S., (2017). The Development of Scientific Identification Theory To Conduct Operation Research In Education Management (SITOREM). IOP Conference. Series: Materials Science And Engineering 166.

[7] Hoy, WK \& Miskel, CG, (2008). Educational administration: Theory. Research, and practice. Singapore: Mc. Graw-Hill.

[8] Lunenburg, F. C and Ornstien AC (2000). Educational administration: concepts and practices. USA: Wadsworth.

[9] Malik, MM \& Tariq,S. (2016). Impact of Emotional Intelligence on Organizational Performance. International Review of Management and Marketing, 6(2), 289-297.

[10] Puspitasari, A., (2006). Emotional Intelligent Parenting: Mengukur emotional Intelligence Anak dan Membentuk Pola Asuh Berdasarkan Emotional Intelligent Parenting. Jakarta: Alex Media Komputindo.

[11] Rajiani, I. (2010). Applying Personality Traits to Predict Loyalty and Neglect among Employees of Bank Jatim Located in 10 Big Cities of East Java (Mc Crae's and Hofstede's Theories on the effect of Culture on Personality Revisited). Jurnal Aplikasi Manajemen,8(3), 617-622.

[12] Rohiat (2008). Manajemen Seko lah; Teori Dasar dan Praktik, Jakarta: Refika Aditama.

[13] Sudarwan, D. (2010.) Kepemimpinan Pendidikan, Bandung. Alpabeta.

[14] Sugiyono (2013). Metode Penelitian Kuantitatif, Kualitatif dan R\&D, Bandung: Alfabeta.

[15] Usman, MU (2000). Menjadi Guru Profesional. Bandung. Remaja Rosdakarya.

[16] Wahyuddin, W. (2016). The Relationship between of Teacher Competence, Emotional Intelligence and Teacher Performance Madrasah Tsanawiyah at District of Serang Banten Higher Education Studies, (6), (1).

Citation: Darmawi, et.al. " Using Scientific Identification Theory for Operational Research in Education for analyzing Teachers' Performance" International Journal of Managerial Studies and Research (IJMSR), vol 7, no. 4, 2019, pp. 21-28. doi: http://dx.doi.org/10.20431/2349-0349.0704003.

Copyright: () 2019 Authors. This is an open-access article distributed under the terms of the Creative Commons Attribution License, which permits unrestricted use, distribution, and reproduction in any medium, provided the original author and source are credited. 